\title{
Partial migration and decreasing migration distance in the Hungarian population of the Common Blackbird (Turdus merula Linnaeus, 1758): Analysis of 85 years of ring recovery data
}

\author{
Zoltán NÉMETH
}

Received: May 18, 2017 - Accepted: June 19, 2017

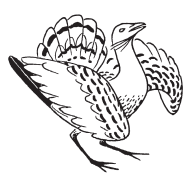

Németh, Z. 2017. Partial migration and decreasing migration distance in the Hungarian population of the Common Blackbird (Turdus merula Linnaeus, 1758): Analysis of 85 years of ring recovery data. - Ornis Hungarica 25(1): 101-108. DOI: 10.1515/orhu-2017-0007 rapidly changing global climate, it is important to understand how migratory birds, including partial migrants, respond to shifting climatic conditions. In this study, I analyzed 85 years of ring recovery data of the Hungarian population of the Blackbird, ringed during the breeding season and recovered during migration or winter, with two objectives in mind: (1) to assess whether the Hungarian Blackbird population is also partially migratory, and (2) to test the prediction that Blackbirds have exhibited decreasing migration distances over the past decades as expected based on warming winter temperatures. Hungarian Blackbirds expressed both migratory and resident strategies, thus can be considered as partial migrants. Furthermore, Blackbirds had been recovered increasingly closer $(-5.9 \mathrm{~km} /$ year $)$ to their breeding grounds in the past decades. Age and sex had no effects on recovery distance. Provided that this trend continues, the adaptive benefits of migratory behavior may eventually be reduced to a level that selection will not maintain it in the population and the Hungarian population becomes entirely sedentary. Surprisingly, $88 \%$ of migrant recoveries were the result of shooting or hunting activities in Mediterranean countries, primarily in Italy, highlighting both the need to understand the effects of hunting pressure on migratory behavior at the population level in songbirds and the urgency to ban the killing of migratory birds in European countries.

Keywords: Eurasian Blackbird, European Blackbird, migratory bird, climate change, hunting, partial migration

Összefoglalás A fekete rigó európai elterjedési területének nagy részén parciális vonuló, ami azt jelenti, hogy a költő populáció egy része ősszel délre vonul, míg a másik része helyben tölti a telet. A globális klímaváltozás jelentős hatást gyakorol a vonuló madarak életét befolyásoló ökológiai tényezőkre is, ezért fontos, hogy ezek szerepét a vonulásban, a parciális vonulóknál is, minél alaposabban megismerjük. Jelen tanulmányban 85 év gyürủmegkerülési adatát elemeztem a Magyarországon a költési időszakban jelölt és később vonulás vagy a telelési időszak alatt bárhol visszafogott fekete rigókra vonatkozóan. Az elemzésnek két célja volt: (1) a fekete rigó populáció parciális vonuló jellegének vizsgálata, illetve (2) a vonulási távolság hosszú távú változásának vizsgálata. A gyürümegkerülések alapján elmondható, hogy a magyar költő populációban vonuló és rezidens egyedek is vannak, így ez a populáció is parciális vonulónak bizonyul. Az évek során a fekete rigók megkerülési távolsága jelentősen $(5,9 \mathrm{~km} / \mathrm{év})$ csökkent, ami megfelel a melegedő téli átlaghőmérsékletek alapján várhatónak. A kor és az ivar nincs hatással a megkerülési távolságra. Ha ez a csökkenő tendencia folytatódik, a vonulási stratégia adaptív előnye idővel megszünhet, és a jelleg eltủnhet a populációból, az teljesen rezidenssé válhat. A gyürümegkerülések meglepően nagy része (88\%) vadászatból, elsősorban Olaszországban lelött madaraktól származik, ami jól illusztrálja a vonuló madarak vadászatának jelentős mértékét a Mediterrán régióban, illetve befolyásolhatja a vonulási távolságról alkotott képünket a gyürümegkerülések elemzése során. A vadászat vonuló énekesmadarak populációira gyakorolt hatásának megismerése illetve e fajok vadászatának betiltása egyre sürgetőbb feladattá vált az Európai Unióban. 
MTA-DE "Lendület" Behavioral Ecology Research Group, Department of Evolutionary Zoology, University of Debrecen, 4032 Debrecen, Egyetem tér 1., Hungary, e-mail: znemeth05@gmail.com

\section{Introduction}

Partial migration is a widespread phenomenon in the animal world, commonly found in birds, particularly in widely distributed species (Dingle 1996). A species is considered partially migratory when part of the breeding population migrates while the rest stays on the breeding ground year round (Lack 1943, Lundberg 1988, Chapman et al. 2011). The ratio of migrants to residents usually changes with latitude suggesting that the decision to migrate is linked to winter survival. In the northern hemisphere, species exhibiting partial migration often have populations consisting of predominantly resident individuals at lower latitudes and populations where most birds migrate at higher latitudes (Newton 2008). At the proximate level, migratory behavior appears to be influenced by a varying degree of interaction between genetic and environmental factors. For example, strong heritability of migratory behavior may maintain partial migration within Blackcap (Sylvia atricapilla) populations (Berthold \& Querner 1982), whereas migration has low heritability in Burrowing Owls (Athene cunicularia) (Ogonowski \& Conway 2009).

Rapid, recent changes in global climate have led researchers to redraw the distribution maps of organisms across the planet (Thomas \& Lennon 1999, Parmesan 2006). The breeding and wintering ranges of migratory birds, along with the timing of their migrations are among the most affected, particularly at higher latitudes and altitudes (Fiedler 2003). Rising global temperatures have been linked to earlier arrival on the breeding grounds (Pulido 2007), shorter migration distances, likely due to shifting wintering ranges (Fiedler et al. 2004, Visser et al. 2009), changing migration routes (Sutherland 1998), and changes in the proportion of migrating individuals as migratory birds are becoming more sedentary (Pulido \& Berthold 2010, Knudsen et al. 2011).

Given the strong environmental effects on the propensity to migrate in many species, partial migrants could serve as excellent model systems to investigate and attempt to predict how rapid, and often unpredictable, environmental change, particularly global climate change, may influence populations of migratory birds (Németh et al. 2013). Specifically, the evolution and maintenance of different migratory strategies and the development and control of the migratory phenotype under different ecological contexts are questions that by studying partial migrants could be easier to answer (Schwabl \& Silverin 1990, Fudickar et al. 2013, Hegemann et al. 2015).

The Common Blackbird (Turdus merula) is a typical partial migrant throughout much of Europe (Schwabl 1983, Lundberg 1985, Main 2002), and is assumed to be partially migratory in Hungary (Csörgő \& Gyurácz 2009), as well, yet formal analyses of this have only been done on limited sets of samples (Csörgő \& Kiss 1986, Ludvig et al. 1991, Móra et al. 1998).

In this study, I analyzed 85 years of ring recovery data of Blackbirds marked in Hungary. My objective is twofold: first, to investigate whether the Hungarian breeding population of the Blackbird is partially migratory, and second, to take advantage of this long-term data 
set and test for a temporal trend in migration distance of this population. Based on the literature, I predicted that, over the past decades, Blackbirds began wintering closer and closer to their breeding grounds.

\section{Methods}

Ring recovery data were acquired from the Hungarian Ringing Center (BirdLife Hungary). The data set spans over 85 years, the earliest recoveries were reported in the 1930s and the last ones come from 2016, and contains 16580 recovery records of 9461 individuals (date of data acquisition: 4.12.2016).

Objective categorization of recoveries as residents or migrants is critical to assess partial migration. I followed Lack's (1943) definition of 'residents', which considers individuals 'residents' if they are recovered at the breeding grounds in the same season when conspecifics are recovered on the wintering grounds. Migratory status therefore depends on the definition of breeding and wintering sites (Helm et al. 2006). However, to objectively decide what could be considered a breeding ground is difficult. One solution to this problem is to plot the distances between the locations of ringing and recovery sites and visually determine the largest gap, a divide between birds recovered relatively close to the ringing site and further away (see Helm et al. 2006, Hegemann et al. 2010). I considered Blackbirds that fall below this divide as residents and the ones with longer recovery distances as migrants for the purpose of this study (Figure 1).

From the data set, I selected records of birds, which were ringed during the breeding season in Hungary (either as a nestling or as an adult) and recovered during migration or in the winter ( $n=2132$ ). These ringing records come from 163 locations with over $70 \%$ of the records belonging to only 11 ringing stations, which are spread across Hungary. In case of multiple recoveries of the same individual, which applied only to residents, I only selected the last record of winter recovery. The characterization of breeding, migration and wintering seasons in this population follows Móra et al. (1998) and Török (1998): the months of March through August are the breeding season, the months of September-October and February are the migration season, and the months of November through January are the wintering season for this population. Naturally, any categorization of this kind will be arbitrary to a certain degree, and will contain some birds that belong to another category. For example, there may be birds that were already on the wintering area in October and some that have not yet left the breeding ground. Yet, at the population level, these categorizations are justified and represent the annual timing of life-history events for the majority of this population.

I tested the prediction that migration distance (i.e. distance between ringing and recovery sites) decreases over time with linear regression using the "car" package (Fox \& Weisberg 2011) in the R statistical environment (R Core Team 2013). 


\section{Results}

Visual inspection of the recovery distances yielded a gap between $40 \mathrm{~km}$ and $276 \mathrm{~km}$, which I used as a threshold for assigning birds to the categories of " $m$ igrants" and "residents". Of the 2132 birds meeting the criteria for the analysis, 171 were classified as migrants and 1961 as residents (Figure 1). Of the 171 migrants, 109 were recovered during winter. Mean recovery distance of wintering migrants is $827.9 \mathrm{~km}$, and the longest recovery distance (1578 $\mathrm{km}$ ) was reported for a bird shot in Mallorca, Spain in 1956. By far the most wintering migrants have been recovered in Italy (92) but recoveries have also been reported from France (14, of which 9 were reported from the island of Corsica), Spain (1), Slovenia (1), and Albania (1). Of the $109 \mathrm{mi}-$ grants, 96 were shot or hunted ( 81 of those in Italy), 3 were captured live, and there was no information received on the rest of the birds besides the ring number.

Recovery distance of migrants

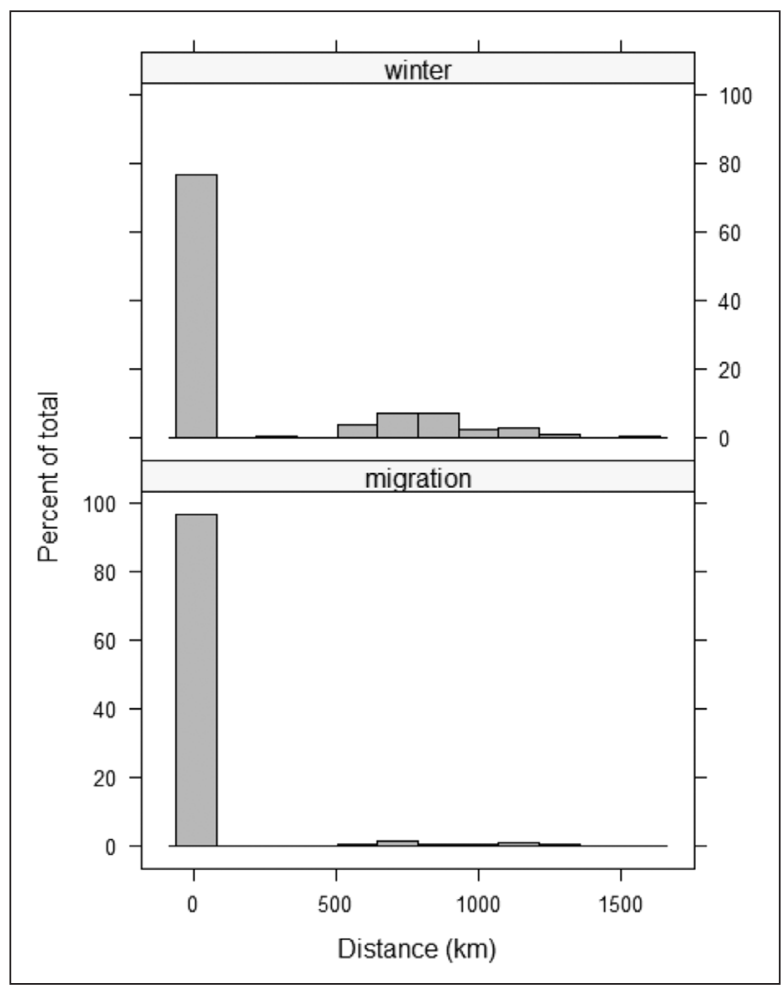

Figure 1. Frequency histograms of recovery distances of Blackbirds captured on the breeding grounds and recovered during migration $(n=1670)$ or winter $(n=462)$

1. ábra A költési időszakban gyűrűzött és vonulási, illetve telelési időszakban visszafogott fekete rigók viszszafogási távolság eloszlása was related to the year of recovery $\left(\mathrm{F}_{1,107}=31.5, \mathrm{p}<0.001\right)$ with an $\mathrm{R}^{2}$ of 0.22 . Recovery distance decreased with an average of $5.9 \mathrm{~km}$ each year (Figure 2). Age upon recovery $\left(\mathrm{N}_{\text {first }}\right.$ calendar year $\left.=46, \mathrm{~N}_{\text {adult }}=59\right)$ and sex $\left(\mathrm{N}_{\text {male }}=37, \mathrm{~N}_{\text {female }}=26\right)$ had no significant effects on recovery distance of wintering migrants (ANCOVA with year as covariant, age $\mathrm{x}$ year: $\mathrm{F}_{3,101}=0.038$, $\mathrm{p}=0.846$; age: $\mathrm{F}_{3,101}=0.152, \mathrm{p}=0.697$; sex $\mathrm{x}$ year: $\mathrm{F}_{3,59}=1.940, \mathrm{p}=0.169$; sex: $\mathrm{F}_{3,59}=0.188$, $\mathrm{p}=0.666$ ).

\section{Discussion}

Analysis of recovery distances in the breeding population of Hungarian Blackbirds revealed both migratory and resident strategies. Therefore, partial migration can be confirmed 
in this population as well. This result is not surprising given that similar conclusions were reached using a smaller subset of ring recovery data (Móra et al. 1998, Csörgö 1991) and by monitoring the wintering ecology of Blackbirds breeding in an urban park (Csörgő \& Kiss 1986, Ludvig et al. 1991). Similarly to the Hungarian Blackbird population, we can find partial migrant populations of Blackbirds in Germany (Schwabl 1983, Fudickar et al. 2013), northern Europe (Snow 1966, 1978, Spencer 1975, Main 2002), and the Netherlands (Van Vliet et al. 2009). In fact, the Dutch Blackbird population appears to have become almost entirely resident in recent decades likely as a consequence of warming climate (Van Vliet et al. 2009).

The prediction that migration distance decreases over time in this Blackbird population was strongly supported by a decrease of $5.9 \mathrm{~km}$ per year in average recovery distance (Figure 2). Although age- and/or sex-dependent latitudinal segregation during winter is a common phenomenon in migrants (Newton 2008), and, based on differences in social dominance, one could expect it to be found in Blackbirds as well (Schwabl 1983, Lundberg 1985), these factors had no significant effects on recovery distance in this population of Blackbirds. Reduction in migration distance has also been reported for the Swedish (Fransson \& Hall-Karlsson 2008) and German Blackbird populations as well, only with a lower rate of change $(-0.14 \mathrm{~km} / \mathrm{year})$ in the latter (Fiedler et al. 2004). Decreasing migration distance as a response to global climate change has been detected in a number of short-distance migrant species all across Europe (Fiedler et al. 2004, Visser et al. 2009, Meller et al. 2016). The primary explanation for this trend is improved access to food sources closer to the breeding grounds facilitated by increasingly milder winter temperatures in recent decades (Meller et al. 2016). This in turn increases winter survival and relaxes selection for

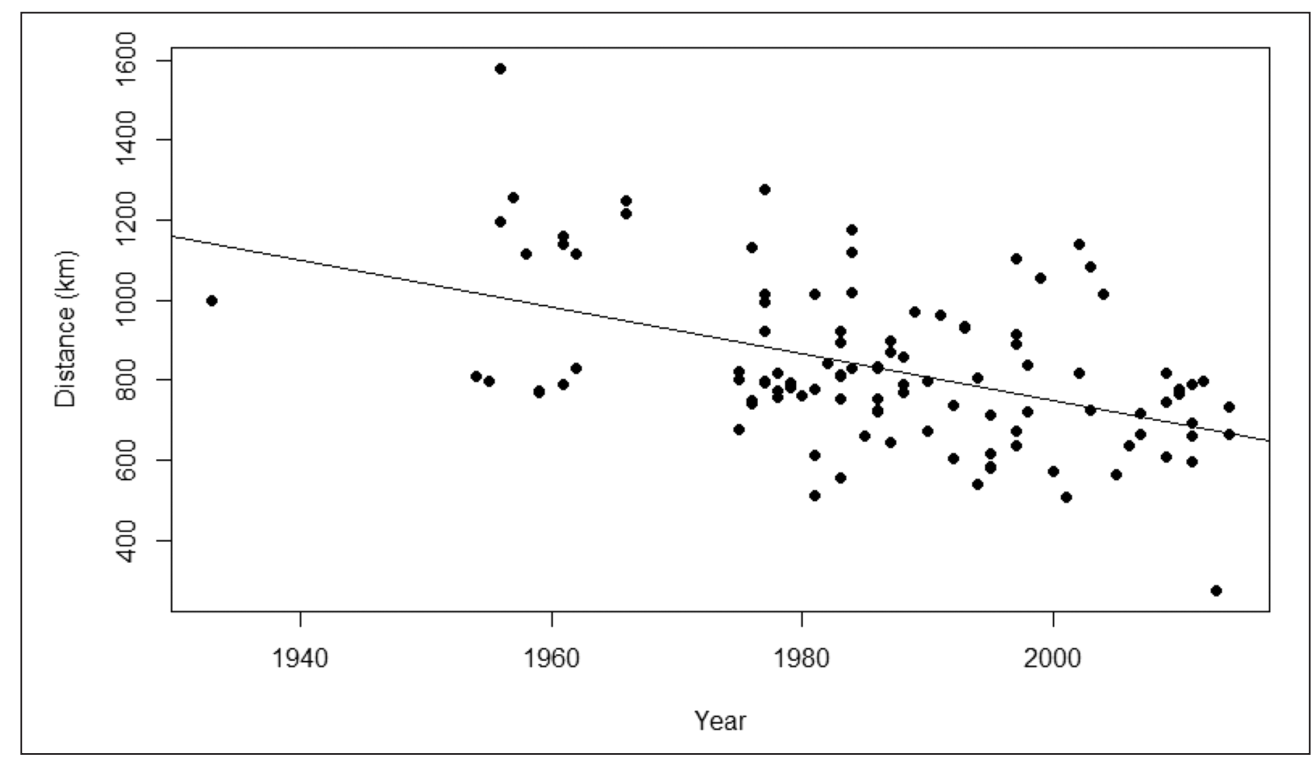

Figure 2. Recovery distances significantly decreased over time in wintering migrant Blackbirds $(n=109)$

2. ábra A fekete rigók megkerülési távolsága szignifikánsan csökkent 
migration. However, there is another significant factor, which cannot be ignored when trying to explain increasingly shorter migration distances and latitudinal shifts in wintering grounds. Hunting pressure for migratory songbirds is remarkably high in countries of the Mediterranean (McCulloch et al. 1992). Indeed, a surprisingly high proportion (88\%) of the recoveries of wintering, migrant Hungarian Blackbirds resulted from shooting or hunting activities. A remarkably high percentage of these (84\%) are reported from Italy. Similarly, hunting in Mediterranean countries contributes a significant number of ring recoveries for migratory bird species breeding in Germany (Fiedler et al. 2004) and in the Netherlands (Visser et al. 2009, Hegemann et al. 2010). It is well known that hunting and illegal trapping of migratory birds can drastically reduce population size (Kamp et al. 2015), and alter migratory behavior and routes (Béchet et al. 2003). Thus, it is important to consider the contribution of hunting, along with climate change, when interpreting ringing recovery data and the associated decrease in recovery distances. Although ring recovery probabilities are generally not uniform geographically (Thorup et al. 2014), it is unlikely that hunting activities have coincidentally shifted closer to Hungary (i.e. breeding grounds) in recent decades leading to a similar spatial distribution of recoveries to what one would expect when the wintering range is shifted northward in response to climate warming. Intensifying hunting pressure in the Mediterranean over the past decades, however, could potentially force migrants to establish wintering areas away from disturbed regions (Madsen \& Fox 1995), and/or could reduce the number of successful longer-distance migrants in a population. Both mechanisms could accelerate selection already at play favoring shorter migration distance or residency due to warming winter temperatures.

Given the current rate of decline in migration distance, the majority of migratory Blackbirds in this population may soon winter near their breeding grounds. Eventually, the adaptive benefits of migration may be reduced to a level that selection will not maintain it in the population and the birds become sedentary, similarly to the Dutch Blackbirds (Van Vliet et al. 2009). Human-induced rapid environmental change offers new, unexplored opportunities along with novel risks for birds to cope with. In the same time, it also provides new model systems for researchers to better understand how successful organisms overcome these “modern" challenges (Németh et al. 2013, Wingfield et al. 2015).

\section{Acknowledgements}

I would like to thank the army of dedicated volunteers, particularly at the larger ringing stations and bird observatories of Hungary (e.g. Ócsa, Tömörd, Szalonna), who contributed countless hours of work to generate this valuable long-term data set. I thank Zsolt Karcza for providing access to the data set, and Zoltán Barta for advice on data management. I am grateful for the constructive comments I received from Emily Cohen, Jeff Buler and Tibor Csörgö on the previous version of the manuscript, and for support from a fellowship from the National Research, Development and Innovation Office of Hungary (NKFIH PD 121013). 


\section{References}

Béchet, A., Giroux, J.-F. Gauthier, G., Nichols, J. D. \& Hines, J. E. 2003. Spring hunting changes the regional movements of migrating Greater Snow Geese. - Journal of Applied Ecology 40: 553-564. DOI: 10.1046/j.1365-2664.2003.00812.x

Berthold, P. \& Querner, U. 1982. Partial migration in birds: experimental proof of polymorphism as a controlling system. - Experientia 38: 805-806. DOI: 10.1007/BF01972282

Chapman, B. B., Brönmark, C., Nilsson, J-Å. \& Hansson, L-A. 2011. The ecology and evolution of partial migration. - Oikos 120: 1764-1775. DOI: 10.1111/j.1600-0706.2011.20131.x

Csörgő, T. \& Kiss, P. 1986. Urbanizált feketerigók (Turdus merula) telelési vizsgálata [Study of overwintering urban Blackbirds (Turdus merula)]. - $2^{\text {nd }}$ Scientific Meeting of the Hungarian Ornithological Society, Szeged, Hungary, pp. 312-316. (in Hungarian with English Summary)

Csörgő, T. 1991. A magyarországi feketerigók (Turdus merula) külföldi megkerüléseinek értékelése [An analysis of recaptures of Hungarian Blackbirds (Turdus merula)]. $-3^{\text {rd }}$ Scientific Meeting of the Hungarian Ornithological and Nature Conservation Society Szombathely, Hunngary, pp. 149-157. (in Hungarian with English Summary)

Csörgő, T. \& Gyurácz, J. 2009. Fekete rigó [Blackbird]. - In: Csörgő, T., Karcza, Zs., Halmos, G., Magyar, G., Gyurácz., J., Szép, T., Bankovics, A., Schmidt, A. \& Schmidt, E. (eds.) Magyar Madárvonulási Atlasz [Hungarian Bird Migration Atlas]. - Kossuth Kiadó Zrt., Budapest, pp. 459-463. (in Hungarian with English Summary)

Dingle, H. 1996. Migration: The biology of life on the move. - Oxford University Press, Oxford

Fiedler, W. 2003. Recent changes in migration behaviour of birds: a compilation of field observations and ringing data. - In: Berthold, P., Gwinner, E. \& Sonnenschein, E. (eds.) Avian migration; recent changes in migratory behaviour of birds: A compilation of field observations and ringing data springer, Berlin, pp. 21-38.

Fiedler, W., Bairlein, F. \& Köppen, U. 2004. Using large-scale data from ringed birds for the investigation of effects of climate change on migrating birds: pitfalls and prospects. - Advances in Ecological Research, Academic Press, pp. 49-67.

Fox, J. \& Weisberg, S. 2011. An $\{$ R $\}$ Companion to Applied Regression. $2^{\text {nd }}$ edition. - Sage Publications, Thousand Oaks, CA.

Fransson, T. \& Hall-Karlsson, S. 2008. Svensk Ringmärkningsatlas Vol. 3. [Swedish Bird Ringing Atlas, Vol. 3.]. - Naturhistoriska Riksmuseet \& Sveriges Ornitologiska Förening, Stockholm, pp. 73-78. (in Swedish with English Summary)

Fudickar, A. M., Schmidt, A., Hau, M., Quetting, M. \& Partecke, J. 2013. Female-biased obligate strategies in a partially migratory population. - Journal of Animal Ecology 82: 863-871. DOI: 10.1111/1365-2656.12052

Hegemann, A., van der Jeugd, H. P., de Graaf, M., Oostebrink, L. L. \& Tieleman, B. I. 2010. Are Dutch Skylarks partial migrants? Ring recovery data and radio-telemetry suggest local coexistence of contrasting migration strategies. - Ardea 98: 135-143. DOI: 10.5253/078.098.0202

Hegemann, A., Marra, P. P. \& Tieleman, B. I. 2015. Causes and consequences of partial migration in a passerine bird. - The American Naturalist 186: 531-546. DOI: 10.1086/682667

Helm, B., Fiedler, W. \& Callion, J. 2006. Movements of European Stonechats Saxicola torquata according to ringing recoveries. - Ardea 94: 33-44.

Kamp, J., Oppel, S., Ananin, A. A., Durnev, Y. A., Gashev, S. N., Hölzel, N., Mishchenko, A. L., Pessa, J., Smirenski, S. M., Strelnikov, E. G., Timonen, S., Wolanska, K. \& Chan, S. 2015. Global population collapse in a superabundant migratory bird and illegal trapping in China. - Conservation Biology 29: 1684-1694. DOI: 10.1111/cobi. 12537

Knudsen, E., Linden, A., Both, C., Jonzen, N., Pulido, F., Saino, N., Sutherland, W. J., Bach, L. A., Coppack, T., Ergon, T., Gienapp, P., Gill, J. A., Gordo, O., Hedenström, A., Lehikoinen, E., Marra, P. P., Møller, A. P., Nilsson, A. L. K., Peron, G., Ranta, E., Rubolini, D., Sparks, T. H., Spina, F., Studds, C. E., Saether, S. A., Tryjanowski, P. \& Stenseth, N. C. 2011. Challenging claims in the study of migratory birds and climate change. - Biological Reviews 86: 928-946. DOI: 10.1111/j.1469-185X.2011.00179.x.

Lack, D. 1943. The problem of partial migration. - British Birds 37: 122-130.

Ludvig, É., Csörgö, T., Török, J. \& Vanicsek, L. 1991. Urbanizált fekete rigók (Turdus merula) telelése [Wintering of urban Blackbirds (Turdus merula) ]. $-3^{\text {rd }}$ Scientific Meeting of the Hungarian Ornithological and Nature Conservation Society, Szombathely, Hungary, pp. 84-98. (in Hungarian with English Summary)

Lundberg, P. 1985. Dominance behaviour, body weight and fat variations, and partial migration in European Blackbirds Turdus merula. - Behavioral Ecology and Sociobiology 17: 185-189. DOI: 10.1007/BF00299250 
Lundberg, P. 1988. The evolution of partial migration in birds. - Trends in Ecology \& Evolution 3: 172-175. DOI: 10.1016/0169-5347(88)90035-3

Madsen, J. \& Fox, A. D. 1995. Impacts of hunting disturbance on waterbirds - a review. - Wildlife Biology 1: 193-207.

Main, I. G. 2002. Seasonal movements of Fennoscandian Blackbirds Turdus merula. - Ringing \& Migration 21: 65-74. DOI: $10.1080 / 03078698.2002 .9674279$

McCulloch, M. N., Tucker, G. M. \& Baillie, S. R. 1992. The hunting of migratory birds in Europe: a ringing recovery analysis. - Ibis 134(Suppl 1): 55-65.

Meller, K., Vähätalo, A.V., Hokkanen, T., Rintala, J., Piha, M. \& Lehikoinen, A. 2016. Interannual variation and long-term trends in proportions of resident individuals in partially migratory birds. - Journal of Animal Ecology 85: 570-580.

Móra, V., Csörgö, T. \& Karcza, Z. 1998. A fekete rigó (Turdus merula) túlélése a partiális vonulás tükrében [Survival of Blackbird (Turdus merula) populations in relation to its migratory status]. - Ornis Hungarica 8 (Suppl. 1): 187-198. (in Hungarian with English Summary)

Németh, Z., Bonier, F. \& MacDougall-Shackleton, S. A. 2013. Coping with uncertainty: Integrating physiology, behavior, and evolutionary ecology in a changing world. - Integrative and Comparative Biology 53: 960964. DOI: $10.1093 /$ icb/ict089

Newton, I. 2008. The migration ecology of birds. - Academic Press, London

Ogonowski, M. S. \& Conway, C. J. 2009. Migratory decisions in birds: extent of genetic versus environmental control. - Oecologia 161: 199-207. DOI: 10.1007/s00442-009-1356-3

Parmesan, C. 2006. Ecological and evolutionary responses to recent climate change. - Annual Review of Ecology, Evolution, and Systematics 37: 637-669. DOI: 10.1146/annurev.ecolsys.37.091305.110100

Pulido, F. 2007. Phenotypic changes in spring arrival: evolution, phenotypic plasticity, effects of weather and condition. - Climate Research 35: 5-23. DOI: 10.3354/cr00711

Pulido, F. \& Berthold, P. 2010. Current selection for lower migratory activity will drive the evolution of residency in a migratory bird population. - Proceedings of the National Academy of Sciences 107: 7341-7346. DOI: 10.1073/pnas.0910361107

R Core Team 2013. R: A language and environment for statistical computing. - R Foundation for Statistical Computing, Vienna, Austria

Schwabl, H. 1983. Ausprägung und Bedeutung des Teilzugverhaltens einer üdwestdeutschen Population de Amsel Turdus merula [Expression and significance of the winter strategies in a partially migratory population of European Blackbirds (Turdus merula)]. - Journal für Ornithologie 124: 101-116. DOI: 10.1007/BF01640158 (in German)

Schwabl, H. \& Silverin, B. 1990. Control of partial migration and autumnal behavior. - In: Gwinner, E. (ed.) Bird Migration: Physiology and Ecophysiology. - Springer Heidelberg, Berlin, Heidelberg, pp. 144-155.

Snow, D.W. 1966. The migration and dispersal of British Blackbirds. - Bird Study 13: 237-255. DOI: $10.1080 / 00063656609476125$

Snow, D.W. 1978. Long-distance movements of British Blackbirds. - Ringing \& Migration 2: 52-54. DOI: $10.1080 / 03078698.1978 .9673738$

Spencer, R. 1975. Changes in the distribution of recoveries of ringed Blackbirds. - Bird Study 22(3): 177-190. DOI: $10.1080 / 00063657509476462$

Sutherland, W. J. 1998. Evidence for flexibility and constraint in migration systems. - Journal of Avian Biology 29: 441-446. DOI: $10.2307 / 3677163$

Thomas, C. D. \& Lennon, J. J. 1999. Birds extend their ranges northwards. - Nature 399: 213-213.

Thorup, K., Korner-Nievergelt, F., Cohen, E. B. \& Baillie, S. R. 2014. Large-scale spatial analysis of ringing and re-encounter data to infer movement patterns: A review including methodological perspectives. - Methods in Ecology and Evolution 5: 1337-1350. DOI:10.1111/2041-210X.12258

Török, J. 1998. Fekete rigó (Turdus merula) [Blackbird]. - In: (Haraszty, L. (ed.) Magyarország madarai. Mezőgazda Kiadó, pp. 288-290. (in Hungarian)

Van Vliet, J., Musters, C. J. M. \& Ter Keurs, W. J. 2009. Changes in migration behaviour of Blackbirds Turdus merula from the Netherlands. - Bird Study 56: 276-281. DOI: 10.1080/00063650902792148

Visser, M. E., Perdeck, A. C., van Balen, J. H. \& Both, C. 2009. Climate change leads to decreasing bird migration distances. - Global Change Biology 15: 1859-1865. DOI: 10.1111/j.1365-2486.2009.01865.x

Wingfield, J. C., Krause, J. S., Perez, J. H., Chmura, H. E., Németh, Z., Word, K. R., Calisi, R. M. \& Meddle, S. L. 2015. A mechanistic approach to understanding range shifts in a changing world: What makes a pioneer? General and Comparative Endocrinology 222: 44-53. DOI: 10.1016/j.ygcen.2015.08.022 